\title{
THE PARADIGM OF ZAKARPATYA GREEK CATHOLIC CHURCH OF UKRAINIAN NATIONAL CONSCIOUSNESS DEVELOPMENT (1771-1867)
}

\author{
GALYNA ROZLUTSKA, MARIANA SOKOL
}

\begin{abstract}
Nowadays under the influence of external dynamic factors, the gap between Ukrainians and the spiritual traditions of the Ukrainian nation is widening. Globalization, internationalization and technologicalization are contributing to the spread of alien ideologies in the Ukrainian society that give rise to the formation of a mercantile-pragmatic outlook in the younger generations. The need for constructive-critical rethinking of the experience of the past and creative interpretation of its positive achievements in the construction of qualitatively new strategies for the spiritual healing of the Ukrainian nation is exacerbated. The aim of the article is to link the influence of the Greek Catholic Church on the formation of the national consciousness of the population of Transcarpathia between 1771 and 1867; identify the socio-historical factors behind the formation of the Greek Catholic Church in Transcarpathia in the context of nationalization; to analyze the cultural, educational and organizational-pedagogical activities of the Greek Catholic clergy.

To achieve this goal, the following methods have been used: analytical and synthetic methods to analyze the source of the study; the problem-chronological method for the coverage of historical events and processes in the ontogenetic development of the ideology of the Greek Catholic Church; comparative-historical method for comparing historical facts and phenomena, revealing their characteristic features; manifestations in the cultural-educational, pedagogical activity of the Greek Catholic clergy.

The scientific novelty of the obtained results is that the socio-political and socio-cultural conditions of the Greek Catholic Church in Transcarpathia in 1771-1867 have been revealed. The leading role of the Greek Catholic Church in national consciousness formation of Transcarpathian Ukrainians, which was structured due to the institutional design of the church, has been identified. The main ideological and political transformations of the Greek Catholic clergy in search of their national nature have been analyzed. On the basis of the analysis of historical events of the period from 1771 till 1867 in the development of the Greek Catholic Church in Transcarpathia it can be outlined the main results of the study such as the isolation of positive features, in particular, the canonization of Mukachevo and Prešov Dioceses, the increasing number of parishes and believers and the falls and negative aspects like manifestations of madyarization. It has been proved that the institutional registration of the church became an effective mechanism of self-identification of Transcarpathian Ukrainians through the preservation of the Church Slavonic language in liturgical services and its support in Hungarian environment. It has been found that national ideas crystallized in the environment of patriotic priests, which, under the pressure of socio-political influences of that era, sought to find their nationality in various ideological directions: Moscow, Austrophil, etc. The conducted research makes it possible to conclude that the institutional design of the Greek Catholic Church in Transcarpathia is conditioned by socio-historical influences, the canonization of Mukachevo and Prešov Dioceses, the increase in the number of parishes and parishioners in the period 1771-1867.
\end{abstract}


Keywords: education, the Greek Catholic Church, national consciousness, Transcarpathia, madyarization.

\section{INTRODUCTION}

European integration processes contribute to the spread of alien ideological denominations in Ukrainian society, along with mercantile-pragmatic axiological priorities. A new generation of Ukrainians is growing up, for whom the main values in life are: material benefits, technological trends, psychotropic substances, etc. At the same time, the gap with the spiritual traditions of the Ukrainian nation is growing. The historical experience, the activities of the Greek Catholic Church in Transcarpathia, which for centuries has been the leader of spiritual, national, moral, cultural values, expression of national self-identification of Ukrainians has been a point of interest in today's realities.

The analysis of recent studies and publications that initiated the study of this problem shows that the diverse activities of the Greek Catholic Church in Transcarpathia require interdisciplinary research. Historical researches of foreign and domestic scientists A. Godynka, F. Molnar, I. Udvari, V. Phenych, A. Shtefan give an opportunity to understand the ethnogenesis of Transcarpathian Ukrainians in historical retrospect. Theological studies of researchers A. Baran, M. Lelecach, A. Pekar reproduce the process of hierarchical registration of the Greek Catholic Church in Transcarpathia However, the role of the church in the national consciousness formation of Ukrainians remains insufficiently disclosed and requires objective study.

The aim of the article is to explore the role of the Greek Catholic Church in national consciousness shaping of Transcarpathia population since 1771 until 1867. According to the aim, the following tasks have been defined: to characterize the influence of social and historical conditions of the Greek Catholic Church formation in Transcarpathia in the context of national formation; to analyze the cultural, educational, organizational, and pedagogical activities of Mukachevo Greek Catholic bishops.

\section{RESULTS AND DiscUSSION}

The hierarchical design of the Greek Catholic Church of Transcarpathia has been expressed by the creation of Mukachevo Greek Catholic Diocese according to the Bulla of Pope Clement XIV, "Eximia Regalium Principium", dated September 19, 1771 [6, p. 70]. The first canonical bishop of the Diocese of Mukachevo was I. Bradach (1768 - 1772), who continued the work of his predecessor, Bishop M. Olszavski, on the construction of the Mukachevo Theological School. During the episcopacy of I. Bradach, teaching at the school lasted up to four years, and its academic level increased significantly due to the involvement of four theology professors [7, p. 137]. I. Bradach personally developed the rules of the internal order of the school [3, p. 16]. It should be emphasized that these rules have been written in the Rus (Ukrainian) language of those days and translated into Latin.

Some historians consider Bishop Bradach to be the author of "Bukvar" and the "Collection of Church Prayers" published in 1770 in the Viennese typography of Kurtzbek [9, p. 59]. During his activity, I. Bradach published a circular (1762), which emphasized the importance of parochial education and upbringing of Rus children and stated the responsibilities of a half-teacher and parents of children attending school [9, p. 72-73]. From this document it is followed that the bishop emphasized the need for systematic teaching and Christian education of children; instructed the priest-teachers to monitor school attendance of children; considered to provide outreach to parents who should consciously approach their children's education and upbringing; ordered the sons of the priests to continue their studies at Mukachevo Theological School. In another letter from the circular of 1769, I. Bradach outlined a program for the education of children in parish schools, in which he saw the driving force behind the development of the Rus (Ukrainian) people, their way out of the darkness [4, p. 14]. 
The fanous bishop A. Bachynskyi (1772 - 1809) played an important role in the unification of Mukachevo Diocese lands, the formation of new vicariates, as well as in the cultural and educational development of the Transcarpathian region. Starting from the reforms of Maria Theresa and thanks to the activity of A. Bachynskyi, the clergy of Mukachevo Diocese turned into a separate privileged state, and the believers were able to understand the content of the liturgical rites and to communicate in their native language. According to various statistics, the bishops' authority of the Bishop of Mukachevo Bachynskyi extended to the territory of 13 of the 45 committees / county of Hungary with a total area of $49074 \mathrm{~km} 2$. As of 1804, 541,963 people have been Greek Catholics of Mukachevo Diocese, representing $7.87 \%$ of the whole population [8, p. 130].

During the reign of A. Bachynskyi, Ukrainian ethnic lands have been united under the jurisdiction of Mukachevo Diocese [1, p. 50-51]. The bishop took care of the education of the local population, so he developed his own program of organizing school education in Hungarian Rus and invited Empress Maria Theresa to participate in its implementation. The committees governments of Abaoui, Bereg, Borshod, Gemer, Zemplin, Maramorosh, Sabolch, Satmar, Spish, Torn, Ugocha, Ung, Sharish and landowners's have been obliged to promote the organization of primary schools for believers of the Eastern rite. In order to provide Greek-Catholic parishes with books in understandable language for parishioners, a list of books necessary for different age categories in Rus (Ukrainian) has been defined. The Catechism of the Italian Cardinal Bellarnin, the Kiev and Nacho poems and books, Greek and Russian clerks published in Lviv have been approved as a model for printing [1, p. 24-25]. During the time of A. Bachynskyi there was a rapid development of national education of the region. At his initiative, public schools were established at Greek Catholic churches in which Rus (Ukrainian) has been the language of teaching. Theological school has been moved to Uzhgorod Castle near the residence of Mukachevo Diocese and reorganized into a powerful multi-stage educational complex. Along with theological training, teacher education has been organized, later first three-month teacher training courses have been organized in the Parish of Koritanya, and then a teacher's seminary has been established. Postgraduate education has been founded, the so-called "home for the Presbyterians", in which graduated theologians with foreign language training studied Church Slavonic liturgical languages and rituals [7, p. 138-139]. Educational and methodological support for native schools has been organized. In 1790, the bishop announced the transfer of 3,000 books to the Diocesan administration in Uzhgorod.

Thus, the organizational and pedagogical activity of A. Bachynskyi has been aimed at the development of public education in Transcarpathia, the introduction of the native language into the educational process of not only elementary but also professional schools, the approximation of the language of religious rites to the traditions of the autochthonous culture of the Transcarpathians. Thus, during the episcopacy of A. Bachynskyi, the national-religious self-awareness of the Transcarpathian Rusyns (Ukrainians) as a separate nationality in multinational Hungary have been occurred, which, at the same time, has been closely related to the Eastern Slavs living abroad.

In the early nineteenth century. The Austrian government began to support the interests of national minorities in order to control the national-state aspirations of people who inhabited the territories of the Hungarian Kingdom. In their turn, the Hungarians sought to weaken the unity of national minorities and therefore fragmented them administratively, politically, economically, even culturally. Whereas, the creation of Mukachevo Diocese testified to the support of the Habsburg court and gave rise to a religious and almost homogeneous ethnically speaking monolith, which accumulated ideas of spirituality, education, catholicity and convincingly expressed the national priorities of Transcarpathians.

In an effort to divide and assimilate the community of Christians of the Eastern Rite, united in Mukachevo Diocese, the Roman Catholic Church hierarchy and Hungarian officials have been engaged in intrigue. Thus, it has been decided to separate the part of Mukachevo Diocese, which formed the ethnic core - the Prešov Region. The Papa's bulla "Relata Semper" of 1818 legalized the creation of the Diocese of Prešov and subordinate to the Metropolitan Authority of the Archbishop of Ostrigue, the Primate of Hungary. The Apostolic See granted the emperor the right of nomination by virtue of his 
patronage over the whole of Hungary, as the "apostolic king". However, before accepting episcopal consecrations, the nominee bishop had to obtain consent from Rome. Each year, Bishop undertook to make a confession of faith, certified by two canons, which was then sent to Vienna by the Apostolic Nuncio. Thus, Prešov Independent Diocese has been under scrutiny by the ecclesiastical administrators of Rome, Vienna, Ostrogom and, as a subsidiary diocese of Mukachevo Greek Catholic Diocese, always looked to the decisions of the Mukachevo lords.

The successor to Bishop J. Gaganets (1842 - 1875) succeeded in achieving the organization of Prešov Greek Catholic Diocese. The administrative capacity of the bishop helped to raise the material level of the clergy, with funds from the diocesan fund have been taken on a monthly basis - Congrua (the lowest state-guaranteed clergy fee). Recognizing European values, which were combined with patriotism, Bishop J. Gaganets began to form a new generation of Greek-Catholic clergy, ready to lead believers in new socio-political conditions [6, p. 87].

Because of the canonization of Mukachevo and mainly Prešov diocese, not only the status of the Uniate clergy has been changed through material support and the introduction of compulsory education, but also the status of the Greek Catholic Church itself, formally equated with other denominations and thus introduced into the system of national life of the empire. All this allowed the clergy to perform not only pastoral functions, but also social responsibilities, which gave him the opportunity to occupy a leading position in the socio-political and cultural-educational processes in Transcarpathia.

In particular, A. Bachynskyi's successors A. Povchiy and V. Popovich were able to organize around themselves a whole galaxy of highly educated church intellectuals (A. Baludianskyi, V. Dovgovich, M. Grigashiy, G. Krychfalushiy, M. Luchkay, I. Fogarashi, I. Churgovich etc.), which influenced the sociopolitical and cultural-educational management of the Transcarpathian region. At the same time, the Greek Catholic clergy, in the eyes of the faithful, represented the social elite, because the peasants only considered priests their masters and identified them with the intelligentsia.

After the Congress of Vienna in 1815, the Habsburg monarchy, frightened by national awakening under the influence of the Napoleonic wars of the Slavic peoples, began to curtail the policy of liberalization among the Slavic population. First, this has been reflected in the introduction of Hungarian as a state language in administrative, military institutions and schools. However, contrary to the processes of forced madyarization, from the 20's of the XIX century Slavic revival influences are actively spreading in the region. The cultural and educational intelligentsia of the Czech Republic, Slovakia, the Dnieper Ukraine, and Poland became the transmitter of the ideas of revival, which resulted in the elements of dynastic loyalty in the mind of the Ruthenian intelligentsia to be combined with new ideas of European romanticism, which stimulated interest in the problems of folk culture, culture.

The rector of the seminary in Uzhgorod, and later in Vienna, I. Fogarash, became the influential figure of the Transcarpathian revival. Under the influence of romantic ideas, I. Fogarash studied the history of the Rusyn language. M. Luchkay holds a leading position among Transcarpathian alarmists. As an inspector of the Uzhgorod school district, he has done much to open rural schools. He composed the first grammar of Rusyn literary language in the Western Ukrainian lands - "Slavic-Rusyn Grammar" (published in Latin in 1830). He is the author of one of the first works in the history of Transcarpathia - the six-volume "History of the Carpathian Rusyns".

The cohort of brilliant Transcarpathian intellectuals of the alarmists of this period also included the famous physicist, mathematician, dean and rector of Lviv University Ivan Zemanchyk, professor of Lviv, Cracow and St. Petersburg Universities Peter Lodiy, economist and lawyer by profession, first rector of St. Petersburg, Riga University Lyceum Ivan Orlay, a famous Slavic scholar, writer, and publicist Yuri Gutz-Venelin.

The revolution of 1848-1849 stopped the actualization of national ideas in Transcarpathia and Greek Catholic priests have been the main carriers of such ideas. Thus, the Diocesan Synod, convened by Bishop of the Prešov Diocese J. Gaganets in June 1848, was the beginning of a religious and national revival of not only Prešov Region but also of the whole Transcarpathia. The ideas of J. Gaganets have 
been expressed in the activities of the episcopal secretary, the canonist Alexander Duchnovich, and subsequently took shape in a social movement, which became known in the history as "Buddhism." Like in Galicia, its inception has been stimulated by the reform policies of the Viennese government. The driving force behind this process was also the Church intellectuals who has been influenced by the ideology of Enlightenment and Romanticism.

At the same time, "Spring of the Peoples" for the Transcarpathian Greek-Catholic clergy has been a turning point in view of the need to choose national and political orientations: to remain loyal to the Habsburg policy, which promoted their privileged position in the country or to stand on the side of the Hungarian movement, which distinguished itself by its nationalism. In this context, it should be noted that L. Koshut's government, by abolishing the privileges of the Catholic Church and proclaiming the equality of all denominations in the territory of the Hungarian Kingdom, was unfriendly to Greek Catholics. The Hungarians considered the Greek Catholic Church to be an inferior religious structure, since it was directly dependent on the Catholic Church. In addition to the above benchmarks, V. Fenich highlights another trend in the views of the Transcarpathian spiritual elite. It is a "view of the East to the Slavic brothers in general and more to the political grandeur of Russia in particular. However, church figures limited themselves to literary and linguistic issues of "affinity" with the Great Russian people“ [10, p. 70]. It is obvious that the revolution of 1848-1849 played a key role in the split of the clergy of the Greek Catholic Church in Transcarpathia, their choice of political landmarks.

Under the pressure of socio-political events of the day, the Transcarpathian Greek-Catholic clergy split into two multi-vector ideological camps - the Muscophilic and the Austrophilic. The representatives of the Muscophilic movement - I. Orlay, Y. Dukhnovych, I. Rakovsky, Y. Hutsa-Venelin professed the idea of cultural federalism of the Slavic peoples, led by Russia. The views of Slavic scholars J. Dobrovsky, J. Jungman. P. Shafarik have been the ideological backgrounds of this concept, they believed that all the Slavic peoples should unite under the branch of the "mighty old oak of Russia" [3, p. 226]. The peculiarity of the concept was that the unification of the Slavic peoples has been seen not as a political rally around Russia but as a "process of cultural unity of the Slavs", the creation of a "literary free Slavic state". Muscophiles builders saw in Russia a guarantor and defender of the rights of the Slavic peoples, and therefore gladly met the Russian army abandoned by Nicholas I to suppress the Hungarian Revolution in Transcarpathia and Hungary.

Under the slogan of the struggle against Hungary and Hungarian influences, the opposite (Austrophilic) camp of Transcarpathian alarmists has been formed. Adolf Dobriansky, who upheld the principle of "Austrian federalism", envisaging the unification of Transcarpathia and Eastern Galicia (which at that time was part of Northern Bukovina) into a separate crown region called "Russian Voivodeship", headed it. However, the Polish aristocrats, who had influence at the Viennese court, strongly opposed the division of Galicia into Ukrainian and Polish parts, and their position has been supported by the Hungarian and Romanian ruling circles. Thus, the ideas of the alarmists did not come to fruition in the public life of Transcarpathia at that time [2, p. 140-143].

The revolutionary events of 1848-1849 revealed that part of the Greek Catholics in Hungary had, if not clearly political but obvious cultural Russian (Moscow) sympathy. This allowed the Hungarian Calvinists to accuse the Rusyn-Ukrainians of promoting the Russian language and culture and the territories of the Hungarian Kingdom. As a result, the Hungarians began to call the Transcarpathian Rusyns by humiliating word -“oroszók" (Russian) [11, p. 84].

The creation of the dualistic Austro-Hungarian monarchy in 1867 had a negative impact on the Greek Catholic Church and the national movement in Transcarpathia. Because of the agreement of Austrian and Hungarian governments, the lands of Transcarpathia, Transylvania, Croatia and Slovenia have been removed to the Hungarian crown. Each empire state, both Austrian and Hungarian, had its own parliament and government. Therefore, Hungary's internal sovereignty allowed it to pursue an assimilation policy towards non-titular nations. Thus, the Law on Equality of All Nationalities of December 6, 1868 stated, "all citizens of Hungary constitute one nation, one indivisible Hungarian nation" [5, p. 39]. 
The Hungarian authorities have been interested in church affairs of Transcarpathia only in the context that the clergy was promoting Hungarian ideas among the common people, seeing in it an effective mechanism for the Madyarization of the Rusyn population. After 1867, the appointment of the Greek Catholic bishops took place through mediation of Hungarian authorities. They elected bishops who obeyed Hungary and promoted the marginalization of the region [6, p. 99]. It is worth to say that in the history of the Greek Catholic Church of Transcarpathia, the period of domination of AustriaHungary has been called as "Dark Ages".

\section{CONCLUSIONS}

In 1771-1867, the Greek Catholic Church in Transcarpathia experienced an upswing (the canonization of the Mukachevo and Prešov Dioceses, an increasing number of parishes and parishioners) and falls (the initial stage of its madyarization). However, it was the institutional design of the Greek Catholic Church that became the clearest manifestation of the national consciousness of Transcarpathian Ukrainians.

The establishment of a mother tongue in religious ceremonies, science and education has been the positive consequence of the confrontation between spiritual leaders and Mukachevo lords in the attempts to denationalize Ukrainians. At the same time, a further scientific interest is a comprehensive study of the development and formation of a system of Greek Catholic schools in Transcarpathia.

The Transcarpathian Greek-Catholic clergy has been an expression of the cultural, educational and socio-political needs of the local population. Moreover, the conservation of the Eastern rite, the use of the Church Slavonic language, the preaching of the vernacular, the creation of a network of parish and monastic schools, the catechization of children, youth and adults created a basis for preserving the features of Russian (Ukrainian) national identity of the Transcarpathian intercarpathian, (the Ukrainians) and the Hungarians, saving them from complete madrization.

\section{REFERENCES}

[1] Baran O. Bishop Andrei Bachinsky and church rebirth in Transcarpathia. Yorkton, Sask, 1963 (in Ukrainian)

[2] Filina T.V. Wakening - a period of struggle for the establishment of Ukrainian national culture. Kultura narodov Prychornomoria, 24 (2001), 140-143. Available at: http://dspace.nbuv.gov.ua/handle/123456789/83269 (in Ukrainian)

[3] Voloshyn A. I. Selected works. VAT Vydavnytstvo Zakarpattia, Uzhhorod, 2002. (in Ukrainian)

[4] Lelekach N. Mukachevo Theological School (1744-1776). Drukarnia Podkarpatskoho Obshchestva Nauk, Unhvar, 1943. (in Ukrainian)

[5] Mahochii P.R. Formation of national consciousness: Subcarpathian Rus (1848-1948). Uzhhorod, 1994. (in Ukrainian)

[6] Pekar A. Essays on the history of the Transcarpathian Church. Tom I: Yerarkhichne oformlennia. Vydannia druhe. Vydavnytstvo Ottsiv Vasylian "Misioner", Rym-Lviv, 1997. (in Ukrainian)

[7] Pekar A. Essays on the history of the Transcarpathian Church. Tom II: Vnutrishnia istoriia. Vydannia druhe. Vydavnytstvo Ottsiv Vasylian "Misioner", Rym-Lviv, 1997. (in Ukrainian)

[8] Udvari I. Examples of the history of Subcarpathian Rusyns of the XVIII century. Studies on the history of culture and language. Udavatelstvo V. Padiaka, Uzhhorod, 2000. (in Ukrainian)

[9] Udvary I. Collection of sources for the study of the Rusyns alphabet II. Bishops Gabriel Blazhovsky, Manuel Olshavsky, John Bradach and their time. Niredhaza, Kiev, 2005. (in Ukrainian)

[10] Fenych V.I. Greek-Catholic Church in the socio-political and cultural life of Transcarpathia (1771-1867). Nauka, Uzhhorod, 1997. (in Ukrainian) 
Address: Galyna Rozlutska, Uzhhorod National University, 3, Narodna Square, Transcarpathian region, Uzhhorod, 388000, Ukraine;

Mariana Sokol, Ternopil Volodymyr Hnatiuk National Pedagogical University, 2, Maxyma

Kryvonosa Str., Ternopil, 46027, Ukraine.

E-mail: grozlutska@ukr.net; maryanasokol@ukr.net

Received: 11.02.2020; revised: 27.03.2020.

Розлуцька Галина, Сокол Мар'яна. Парадигма Греко-Католицької Церкви у формуванні національної свідомості закарпатців. Журнал Прикарпатського університету імені Василя Стефаника, 7 (1) (2020), $57-63$.

Під впливом зовнішніх динамічних чинників поглиблюється розрив українців із духовними традиціями української нації. Глобалізація, інтернаціоналізація технологізація сприяють поширенню в українському суспільстві чужих ідеологій, які породжують формування меркантильнопрагматичного світогдяду у підростаючих покодінь. Загострюється потреба конструктивнокритичного переосмислення досвіду минулого і творчої інтерпритації його позитивних здобутків у побудові якісно нових стратегій духовного оздоровлення української нації. Метою дослідження $є$ з'язувати вплив Греко-Католицької Церкви на формування національної самосвідомості населення Закарпаття у період між 1771 та 1867 роками; виявити суспільно-історичні чинники становлення Греко-Католицької Церкви на Закарпатті у контексті націєтворення; проаналізувати культурноосвітню та організаційно-педагогічну діяльність греко-катодицького духовенства.

Для досягнення поставленої мети нами використано аналітико-синтетичні методи для аналізу джерельної бази дослідження; проблемно-хронологічний метод для висвітлення історичних подій та процесів в онтогенетичному розвитку ідеології греко-католицької церкви; порівняльно-історичний метод для порівняння історичних фактів та явищ, виявлення їх характерних ознак, проявів у культурно-освітній, педагогічній діяльності греко-католицького духовенства.

Наукова новизна одержаних результатів полягає у тому, що розкрито суспільно-політичні та соціокультурні умови злету греко-католицької церкви на Закарпатті у 1771 - 1867 рр. Визначено провідну роль греко-католицької церкви у формуванні національної свідомості українців Закарпаття, яка структурувалась саме завдяки інституційному оформленню церкви. Проаналізовано основні ідеологічно-політичні трансформації греко-католицького духовенства у пошуках свого національного єства. Основними результатами проведеного дослідження є виокремлення на підставі аналізу історичних подій періоду з 1771 - 1867 рр. у розвитку Греко-Католицької церкви на Закарпатті, позитивних особливостей, зокрема, канонізації Мукачівської та Пряшівської єпархій, збільшення кількості парафій та вірників і падінь та негативних - прояви мадяризації. Доведено, що інституційне оформлення церкви стало дієвим механізмом самоідентифікації закарпатських українців через збереження у богослужіннях церковнослов'янської мови, обстоювання ії в угорському середовищі. 3'ясовано, що національні ідеї кристалізувались у середовищі патріотів-священиків, які під тиском суспільно-політичних впливів тієї доби шукало своє національне єство у різновекторних ідеологічних напрямах: москвофільських, австрофільських, тощо. Проведене дослідження умождивлюе висновки, інституційне оформлення Греко-Католицької Церкви на Закарпатті зумовлене суспільноісторичними впливами. Канонізація Мукачівської та Пряшівської єпархій, збільшення кількості парафій та вірників у період з 1771 по 1867 рр. Водночас Греко-Католицька Церква на Закарпатті актуалізувала спроби мадяризації. Позитивним наслідком протистояння духовних дідерів, мукачівських владик спробам денаціоналізації українців стало утвердження рідної мови у релігійних обрядах, науці та освіті. Водночас подальший науковий інтерес становить всебічне дослідження розвитку і становлення системи греко-католицьких шкіл на Закарпатті.

Кдючові слова: освіта, Греко-Католицька Церква, національна самосвідомість, Закарпаття, мадяризація. 